\section{Vibriosis in Fish: A Review on Disease Development and Prevention}

By: Ina-Salwany, MY (Ina-Salwany, M. Y.) ${ }^{[1,2]}$; Al-saari, N (Al-saari, Nurhidayu) ${ }^{[2,3]}$; Mohamad, A (Mohamad, Aslah) ${ }^{[2]}$; Mursidi, FA (Mursidi, Fathin-Amira

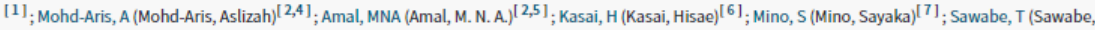
Tomoo) ${ }^{[7]} ;$ Zamri-Saad, M (Zamri-Saad, M.) ${ }^{[2,8]}$

View Web of Science ResearcherID and ORCID

JOURNAL OF AQUATIC ANIMAL HEALTH

Volume: 31 Issue: 1 Pages: $3-22$

DOI: 10.1002/aah.10045

Published: MAR 2019

Document Type: Review

View Journal Impact

\section{Abstract}

Current growth in aquaculture production is parallel with the increasing number of disease outbreaks, which negatively affect the production, profitability, and sustainability of the global aquaculture industry. Vibriosis is among the most common diseases leading to massive mortality of cultured shrimp, fish, and shellfish in Asia. High incidence of vibriosis can occur in hatchery and grow-out facilities, but juveniles are more susceptible to the disease. Various factors, particularly the source of fish, environmental factors (including water quality and farm management), and the virulence factors of Vibrio, influence the occurrence of the disease. Affected fish show weariness, with necrosis of skin and appendages, leading to body malformation, slow growth, internal organ liquefaction, blindness, muscle opacity, and mortality. A combination of control measures, particularly a disease-free source of fish, biosecurity of the farm, improved water quality, and other preventive measures (e.g., vaccination) might be able to control the infection. Although some control measures are expensive and less practical, vaccination is effective, relatively cheap, and easily implemented. In this review, the latest knowledge on the pathogenesis and control of vibriosis, including vaccination, is discussed.

\section{Keywords}

KeyWords Plus: ASIAN SEA-BASS; OUTER-MEMBRANE PROTEIN; GROUPER EPINEPHELUS-COIOIDES; FORMALIN-INACTIVATED VACCINE; POSSIBLE PROBIOTIC TREATMENT; LARGE YELLOW CROAKER; SALMON SALMO-SALAR; LATES-CALCARIFER; AEROMONAS-HYDROPHILA; VIRULENCE FACTORS

\section{Author Information}

Reprint Address: Ina-Salwany, MY (reprint author)

+ Univ Putra Malaysia, Dept Aquaculture, Fac Agr, Serdang 43400, Selangor, Malaysia.

Reprint Address: Ina-Salwany, MY (reprint author)

+ Univ Putra Malaysia, Inst Biosci, Lab Marine Biotechnol, Serdang 43400, Selangor, Malaysia. Addresses:

+ [1] Univ Putra Malaysia, Dept Aquaculture, Fac Agr, Serdang 43400, Selangor, Malaysia

+ [2] Univ Putra Malaysia, Inst Biosci, Lab Marine Biotechnol, Serdang 43400, Selangor, Malaysia

- [3] Int Islamic Univ Malaysia, Int Inst Halal Res \& Training, KICT Bldg, Level 3, Gombak 53100, Selangor, Malaysia Organization-Enhanced Name(s) International Islamic University Malaysia

+ [4] Univ Teknol MARA, Sch Biol, Dept Biol, Kampus Kuala Pilah, Kuala Pilah 72000, Negeri Sembilan, Malaysia

+ [5] Univ Putra Malaysia, Fac Sci, Dept Biol, Serdang 43400, Selangor, Malaysia

+ [6] Hokkaido Univ, Fac Fisheries Sci, Lab Fish Pathol, 3-1-1 Minato Cho, Hakodate, Hokkaido 0418611, Japan

+ [7] Hokkaido Univ, Fac Fisheries Sci, Lab Microbiol, 3-1-1 Minato Cho, Hakodate, Hokkaido 0418611, Japan

+ [8] Univ Putra Malaysia, Fac Vet Med, Dept Vet Lab Diag, Serdang 43400, Selangor, Malaysia

E-mail Addresses: salwany@upm.edu.my

Funding

\begin{tabular}{|l|l|}
\hline Funding Agency & Grant Number \\
\hline Inisiatif Putra Berkumpulan, Universiti Putra Malaysia & 9484102 \\
\hline Ministry of Higher Education via the Higher Institution Centre of Excellence & 6369100 \\
\hline
\end{tabular}

View funding text

Publisher

WILEY, 111 RIVER ST, HOBOKEN 07030-5774, NJ USA

Journal Information

Impact Factor: Journal Citation Reports

Categories / Classification

Research Areas: Fisheries; Veterinary Sciences

Web of Science Categories: Fisheries; Veterinary Sciences

See more data fields

\begin{tabular}{l}
\hline A Export.. \\
\hline EndNote Desktop
\end{tabular}

Create Citation Alert

All Times Cited Counts

10 in All Databases

See more counts

\section{8}

Cited References

View Related Records

Most recently cited by:

Hirano, Takako; Okubo, Manabu; Tsuda, Hironobu; et al.

Chittin Heterodisaccharide, Released from Chittin by Chittinase and Chittin

Oligosaccharide Deacetylase, Enhances

the Chitin-Metabolizing Ability of Vibrio

parahaemolyticus.

JOURNAL OF BACTERIOLOGY (2019)

YI, Che-Chun; Lu, Chun-Hung; Chuang.

Kuo-PIn; et al.

A potentlal problotic Chromobacterlum aquaticum with bacterlocin-like activity enhances the expression of Indicator genes assoclated with nutrient metabolism, growth performance and

Innate Immunity agalnst pathogen

Infections in zebrafish (Danlo rerlo).

FISH \& SHELLFISH IMMUNOLOGY (2019)

View All

Use in Web of Science

Web of Science Usage Count

21

35

Last 180 Days $\quad$ SInce 2013

Learn more

This record is from

Web of Science Core Collection

Sclence Citation Index Expanded

Suggest a correction

fyou would like to Improve the quallty of the data in this record, please suggest $a$ correction. 